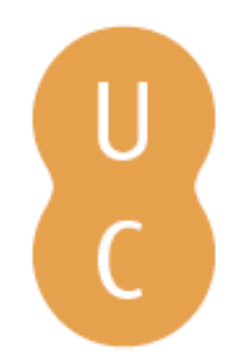

\title{
nombalina
}

\section{Characterisation of the macroinvertebrate benthic communities in the Mondego Estuary}

\author{
Autor(es): $\quad$ Marques, João Carlos; Pardal, Miguel Ângelo; Maranhão, Paulo \\ Publicado por: Imprensa da Universidade de Coimbra \\ URL \\ persistente: URI:http://hdl.handle.net/10316.2/32672 \\ DOI: $\quad$ DOI:http://dx.doi.org/10.14195/978-989-26-0336-0_11 \\ Accessed : $\quad$ 26-Apr-2023 13:43:55
}

A navegação consulta e descarregamento dos títulos inseridos nas Bibliotecas Digitais UC Digitalis, UC Pombalina e UC Impactum, pressupõem a aceitação plena e sem reservas dos Termos e Condições de Uso destas Bibliotecas Digitais, disponíveis em https://digitalis.uc.pt/pt-pt/termos.

Conforme exposto nos referidos Termos e Condições de Uso, o descarregamento de títulos de acesso restrito requer uma licença válida de autorização devendo o utilizador aceder ao(s) documento(s) a partir de um endereço de IP da instituição detentora da supramencionada licença.

Ao utilizador é apenas permitido o descarregamento para uso pessoal, pelo que o emprego do(s) título(s) descarregado(s) para outro fim, designadamente comercial, carece de autorização do respetivo autor ou editor da obra.

Na medida em que todas as obras da UC Digitalis se encontram protegidas pelo Código do Direito de Autor e Direitos Conexos e demais legislação aplicável, toda a cópia, parcial ou total, deste documento, nos casos em que é legalmente admitida, deverá conter ou fazer-se acompanhar por este aviso.

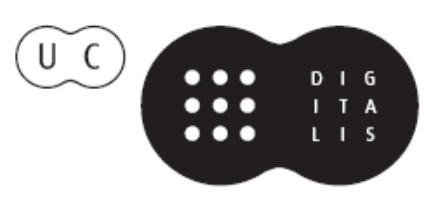


MIGUEL ÂNGELO PARDAL JOÄO CARLOS MARQUES MANUEL AUGUSTO GRAÇA Scientific Editors

\section{Aquatic Ecology of the Mondego River Basin Global Importance of Local Experience}




\author{
MIGUEL ÂNGELO PARDAL \\ JOẢO CARLOS MARQUES \\ MANUEL AUGUSTO GRAÇA \\ Scientific Editors
}

\title{
Aquatic Ecology of the Mondego River Basin Global Importance of Local Experience
}




COORDENAÇÃO EDITORIAL
Imprensa da Universidade de Coimbra
CONCEPÇÃO GRAFICA
António Barros
INFOGRAFIA
António Resende
Estimulus [design] • Coimbra
EXECUÇÃO GRAFICA
GRAFIASA
ILUSTRAÇÃO DA CAPA
P. P. Cunha e ]. Dinis
ISBN
972-8704-04-6
DEPOSITO LEGAL
I75038/02

(C) JANEIRO 2002, IMPRENSA DA UnIVERSIDADE DE COIMBRA

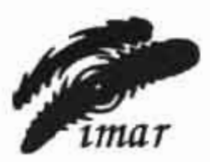

CPIMAR

imar

OBRA PUBLICADA COM O PATROCINIO DE:

IMAR - INSTITUTO DO MAR

IPIMAR - INSTITUTO DE INVESTIGAÇĀO DAS PESCAS E DO MAR 



\author{
Joáo Carlos Marques ' \\ Miguel Ângelo Pardal ' \\ Paulo Maranhä́ '
}

\title{
CHARACTERISATION OFTHE MACROINVERTEBRATE BENTHIC COMMUNITIES INTHE MONDEGO ESTUARY
}

\begin{abstract}
The Mondego estuary is under severe environmental stress, but despite the increasing pressure, until 1985 there was no reference data on the Mondego estuary on which further studies on the impact of human activities over the structure and functioning of the ecosystem could be based. From 1985 to 1990 a reference study on the benthic communities was carried out, regarding both the intertidal and subtidal zones, aiming to characterise the macrobenthic communities structure in relation to physicochemical environmental factors and identify the most important species, which could play a key role in the ecosystem functioning. The intertidal communities were surveyed in December 1986 and July 1987, while the subtidal communities were seasonally studied from December 1989 to September 1990.

With regard to the intertidal area, the community's structure revealed differences between the two arms of the estuary for populations densities and diversity, which was consistent with results from the analysis of physicochemical data. The south arm appears to be less affected by human activities, presenting more favourable conditions for the development of abundant populations of typical estuarine species. Salinity was the most important factor controlling the distribution of hard substrates organisms, while particles size and organic matter contents of sediments, salinity, and dissolved oxygen are the most important factors for soft substrates organisms. Spartina maritima and Zostera nolti marshes, mainly located in the middle section of the south arm, extibited the richest macrofaunal composition with regard to abundance and diversity.

The subtidal macrofauna in the Mondego estuary appears to be clearly impoverished. In the south arm, the macrobenthic community consists mainly of infaunal species and appears to be more stable and structured, presenting higher macrofauna abundance. On the contrary, sparse mobile epibenthic species populations mainly characterise the north arm community, exhibiting a lower biodiversity and an impoverished macrofauna, compared to the south arm. The subtidal communities appear to be physically controlled, with emphasis on the type of sediment, salinity, and currents, and biologically, due to their distinct physicochemical characteristics. The two
\end{abstract}

(1) IMAR - Instituto do Mar, Centro Interdisciplinar de Coimbra, a/c Departamento de Zoologia, Universidade de Coimbra 3004 - 517 Coimbra, Portugal 
arms of the estuary can be considered different sub-systems. Due to harbour facilities dredging takes place regularly along the north arm, and time intervals between dredging operations appear to be inadequate to allow macrofauna recovery.

As a whole, the south arm community appears to be structurally more stable. but due to the feeble water circulation may be more exposed to environmental changes. Monitoring of the Mondego estuary biological communities was considered clearly necessary to assess temporal trends and to establish if the ongoing environmental changes are reversible.

Results from these studies were published in two previous papers (Marques et al. 1993 a, 1993 b).

\section{Introduction}

The Mondego. due to a set factors previously described, may be considered under a severe increase of environmental stress. But despite the increasing pressure, until 1985 there was no reference data on the Mondego estuary on which further studies on the impact of human activities over the structure and functioning of the ecosystem could be based.

From 1985 to 1990 reference studies on the benthic communities were carried out, regarding the intertidal area. in December 1986 and July 1987, and the subtidal zone, from December 1989 to September 1990. The aim of these studies was:

a) To characterise the macrobenthic communities structure in relation to physicochemical environmental factors:

b) To identify the most important species, which could play a key role in the ecosystem functioning;

c) To provide reference information to assess afterwards the impact of human activities on the communities structure and functioning.

The results of these studies were previously published in two independent papers, regarding respectively the intertidal (Marques et al. 1993 a) and the subtidal communities (Marques et al. 1993 b).

\section{Material and methods}

Intertidal sampling programme

In December 1986 and July 1987 quantitative samples were carried out at 19 sampling stations (figure I) to characterise the structure of the intertidal communities in winter and summer situations. Each time, sampling took place during five consecutive days, always in the moming and during a 3 hours period in low water. This allowed samples to be carried out in approximately uniform conditions. 


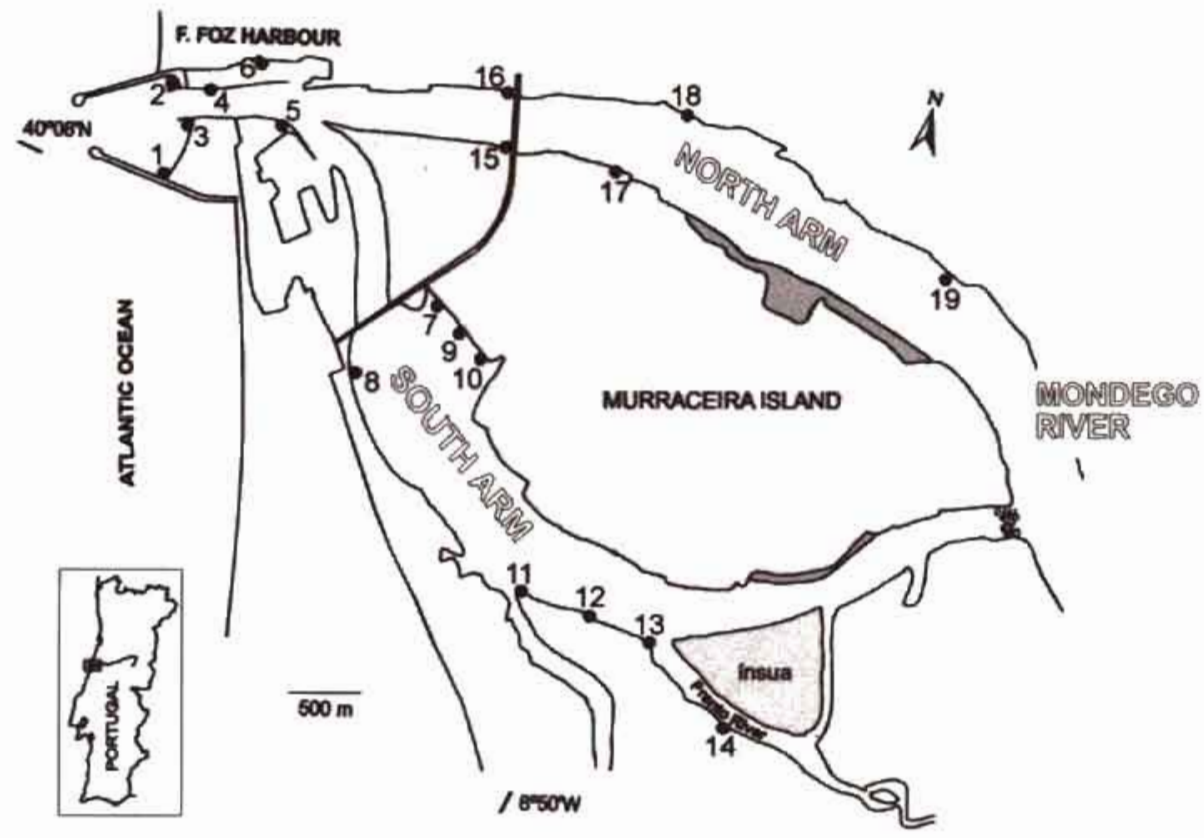

Figure 1. The Mondego estuary Localization of the intertidal sampling stations.

Both hard and soft substrates were frequently found at the same sampling station. and depending on slope the area of the intertidal zone was quite variable. On soft substrates, Spartina maritima and Zostera noltii marshes could be present or not.

In order to establish a uniform sampling criterion, at each station the intertidal zone was stratified, taking into consideration different eulittoral levels, and the type of macroalgae or macrophytes covered areas. This criterion allowed considering three approximately equidistant levels between high water and low water levels. On hard substrates, depending on the sampling site, the two upper levels corresponded approximately to Enteromorpha spp. and Fucus spp. algal belts, whereas the lower level in stations located near the mouth of the estuary presented also a significant population of Mytilus galloprovincialis (mussels). On soft substrates with vegetal covered areas the two upper levels frequently corresponded respectively to the marsh-grass Spartina maritima belt and to the eelgrass Zostera noltii meadows, while the lower level corresponded mainly to sandy or muddy substrates without macrophytes.

Two different sampling techniques were used as a function of the type of substrate. On hard substrates three replicates of $625 \mathrm{~cm}^{2}$ were randomly sampled in each level by scratching out organisms with a chisel. On soft substrates we adapted the technique described by Dexter (1979. 1983) for sandy beaches, and eight replicates were randomly sampled in each level by using a manual corer (each core corresponding to $141 \mathrm{~cm}^{2}$ and approximately 3 litres of sediment).

All biological samples were sieved in situ using a $1 \mathrm{~mm}$ mesh size sieve, and then fixed in $4 \%$ neutralised formaldehyde. This mesh size was considered suitable for this study, regarding the types of sediment we expected to find along the estuary. 
Each time and for each station, several physicochemical factors were determined, respectively salinity, temperature, $\mathrm{pH}$, dissolved oxygen (measured in situ), nitrites, nitrates, and phosphates (analysed in the laboratory). The analysis of water samples followed the methods described in Strickland and Parsons (1968). Sediment samples were also collected and subsequently analysed for particles size, organic matter and carbonate contents.

For each sediment sample, particles were ranked into eight size categories (table I):

TABLE I Particle - size categories used to classify sediment types in the present study

\begin{tabular}{ccc}
\hline Size class & Diameter $(\mathrm{mm})$ & Sediment classification \\
\hline 1 & $>2$ & Gravel \\
\hline 2 & 1 to 2 & Coarse sand \\
\hline 3 & 0.5 to 1 & Medium sand \\
\hline 4 & 0.250 to 0.5 & Fine sand \\
\hline 5 & 0.125 to 0.250 & Silt \\
\hline 6 & 0.063 to 0.125 & \\
\hline 7 & 0.002 to 0.063 & Clay \\
\hline 8 & $<0.002$ &
\end{tabular}

The organic mater content in the sediments was calculated after destruction in a muffle furnace ( 8 hours at $500^{\circ} \mathrm{C}$ ).

In the laboratory the organisms were separated, preserved in $70 \%$ ethanol or in $4 \%$ neutralised formaldehyde, according to the presence or absence of calcareous parts, and identified and counted.

\section{Subtidal sampling programme}

In December 1989 and March, June, and September 1990 quantitative samples were taken at 13 sampling stations ( $A$ to $M$ ) (figure 2), to allow a seasonal characterisation of the subtidal macrobenthic communities. Each time samples were taken over a two days period, during high water of spring tides. At each station six

i72 replicates were sampled randomly, using a small Van Veen grab, capable of collecting up to $5 \mathrm{~L}$ of sediment, operated from a boat The number of replicates per sample was settled by using the rank-frequency diagram method (Frontier 1983) for stabilising variability. Although the sampled area was approximately constant $\left(496 \mathrm{~cm}^{2}\right)$, the amount of sediment collected was not, depending on bottom compactness. A certain degree of bias was therefore introduced into the sampling strategy.

The biological samples, both in the field and the laboratory, were treated the same way as indicated above, and physicochemical factors were also determined each time and for each station, following the same methodology. 


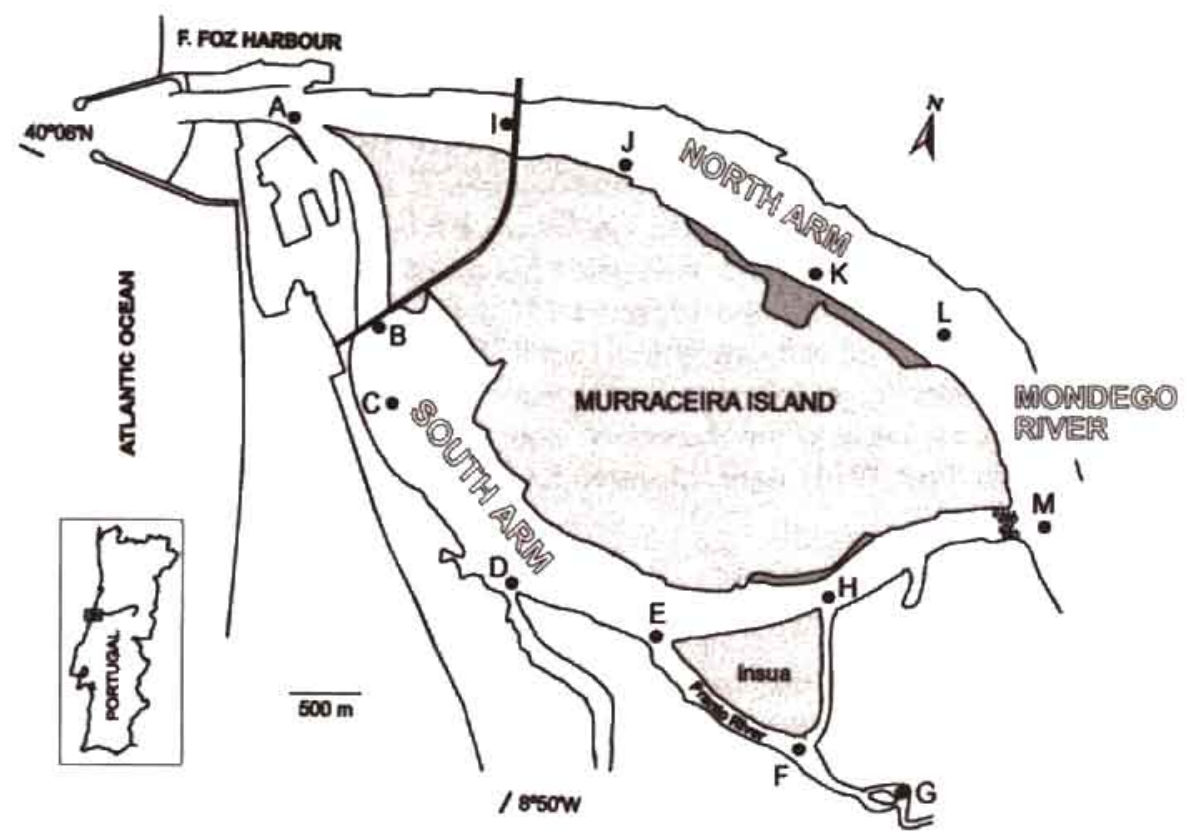

Figure 2 The Mondego estuary, Location of the subtidal sampling stations.

\section{Data analysis}

Intertidal communities

Data on both hard and soft substrates and on winter and summer situations were assumed to correspond to different ecological conditions, and therefore were analysed separately.

With regard to biological data, species $X$ stations matrices were analysed, considering data on each sampling site as a whole. The goal of the analysis was to study the horizontal distributional ecology of the species along the estuary and to reveal differences between the two estuarine arms with regard to community's structure. A first analysis was achieved taking into consideration all the species, and a second one overlooking the species found only once (Legendre and Legendre 1984).

On hard substrates, since it was not possible to collect water in each sampling level, water samples for determination of physicochemical factors were always taken from the water column (one sample per station). On soft substrates, because of water retention in pools during low tide, it was always possible to get water and sediment samples in each sampling level. Consequently, in the first case, we analysed factors $X$ stations matrices, while in the second case the analysis was based upon factors $X$ samples matrices.

Data underwent principal component analysis (PCA), using the sampling stations or the samples as operational units in the space of biological or physicochemical 
variables. Sediment particles size fractions (expressed in \%) and dissolved oxygen (\% of saturation) were both submitted to angular transformation. Eigenvalues and eigenvectors of correlation matrices between variables were computed after centering and reduction to unit variance (Legendre and Legendre 1984). Correlation matrices were computed using the Pearson's correlation index. In addition, biological data was submitted to cluster analysis, using the Chi-Square distance coefficient (Lebart et al. 1984) ( $Q$ mode analysis) and the unweighted pair group mean of analysis (UPGMA) clustering method (Legendre and Legendre 1984). Data treatment was effectuated with the NTSYS-PC 1.60 software system (Rohlf 1990).

Finally, in order to get information on species richness and evenness in different estuarine areas, the values of the Shannon-Wiener heterogeneity index (Legendre and Legendre 1984. Peet 1974) were calculated for each sampling station in winter and summer situations.

Subtidal community

It was also assumed that data for each season should correspond to distinct ecological conditions, and were therefore analysed separately.

With regard to the biological data, seasonal matrices of taxa $X$ stations were analysed, considering data from each station (a series of six replicates) as a whole. In this case. biological data underwent Correspondence Analysis (CA). The Chi-Square Distance coefficient (Lebart et al. 1984) was used to calculate the association matrices for the column (stations) variables. The eigenvalues and eigenvectors for the columns were then computed, followed by the computation of the row (taxa) vectors by projection.

Like before, the Shannon-Wiener heterogeneity index was used to assess biological diversity. Moreover, and as described above, physicochemical data on water and sediments underwent principal component analysis (PCA). The same software was used to perform multivariate data analysis.

\section{Results}

\section{A - Intertidal zone}

We identified 90 macrofaunal species from samples carried out in winter and summer situations (table II). A first look to data confirmed our primary assumptions for 174 data analysis, showing that 34 taxa (38\%) were found only in the winter, while 19 (21\%) were found exclusively in the summer, reflecting a seasonal variation in the species composition. Moreover, 36 taxa (40\%) were found exclusively on hard substrates, while $24(27 \%)$ occurred only in soft substrates, exhibiting a different species composition as a function of the type of substrate.

Table II - List of the taxa identified in winter and summer situations, and on both hard and soft substrates. For each taxa, the average density (number of individuals. $\mathrm{m}^{-2}$ ) is given. 


\begin{tabular}{|c|c|c|c|c|c|}
\hline \multirow[t]{2}{*}{ Taxa } & \multicolumn{2}{|c|}{ Winter } & \multicolumn{2}{|c|}{ Summer } & \\
\hline & $\begin{array}{c}\text { Hard } \\
\text { substrates }\end{array}$ & $\begin{array}{c}\text { Soft } \\
\text { substrates }\end{array}$ & $\begin{array}{c}\text { Hard } \\
\text { substrates }\end{array}$ & $\begin{array}{c}\text { Soft } \\
\text { substrates }\end{array}$ & \\
\hline TURBELLARIA & & & & & \\
\hline $\begin{array}{l}\text { Convoluta sp } \\
\text { NEMERTINI }\end{array}$ & & 0.7 & 0.4 & 0.6 & \\
\hline Lineus sp & 4.2 & & & & \\
\hline Oerstedio sp & & 2.8 & 0.4 & & \\
\hline Tetrastemma sp & & 3.5 & 2. & 0.6 & \\
\hline Paloenemerteo & & & & 0.6 & \\
\hline OLIGOCHAETA & & 0.7 & & & \\
\hline POLYCHAETA & & & & & \\
\hline Eteone picto & & 6.3 & & & \\
\hline Glycero convoluto & & 4.2 & & & \\
\hline Lepidonotus clava & & & 0.4 & & \\
\hline Nephthys cirrosa & & 0.7 & & & \\
\hline Hediste diversicolor & 10.8 & 661 & 13.2 & 890 & \\
\hline Neanthes irrorato & & 28 & 0.4 & & \\
\hline Phyllodoce sp & 1.4 & & & & \\
\hline Polydora sp & & & 2.9 & & \\
\hline Amage adspersa & & 34.6 & 2 & 128 & \\
\hline Amphictheis gunneri & & 17 & & & \\
\hline Copitella capitota & & 4.8 & 0.8 & 30.3 & \\
\hline Girrotulus cirratus & 0.5 & & & & \\
\hline Heteromastus filiformis & & 72.9 & & & \\
\hline Lagis koreni & & 2.8 & & & \\
\hline Mercierella enigmatica & & & 4.4 & & \\
\hline Pomotocerus triqueter & 9.4 & 0.7 & & & \\
\hline Pseudomalacocerus cantabra & & 8.4 & & & \\
\hline Pygospio elegans & & 0.7 & & & \\
\hline Sabelloria alveolato & 2.4 & & & & \\
\hline Spio filicornis & & 3.5 & & 3.7 & \\
\hline Streblospia dekhuyzeni & & 24.5 & 2.4 & 23.9 & \\
\hline Sabellidae & & & 0.4 & & \\
\hline POLYPLACOPHORA & 0.5 & & & & \\
\hline Lepidochitono anereus & 0.5 & & & & \\
\hline GASTROPODA & & & & & \\
\hline Bittium reticulatum & & & & 0.6 & 175 \\
\hline Cerithium vulgotum & & & & 0.6 & \\
\hline Gibbula umbilicalis & & & & 0.6 & \\
\hline Haminea hydatilis & 30 & 200 & & 0.6 & \\
\hline Hydrobia ulvoe & 52.2 & 1980 & 181 & 859 & \\
\hline Littorina littorea & 0.5 & 15.4 & & 10 & \\
\hline Littorina neritoides & 2.8 & & & & \\
\hline Littorina saxatilis & & & & 0.6 & \\
\hline Murex trunculus & 0.9 & & & & \\
\hline Nassanius retrculatus & & & & 5 & \\
\hline
\end{tabular}


Nucella lopillus

Odostomia unidentota

0.9

Patello ospero

0.5

Patella lusitonica

1.4

Rissoa membranocea

0.5

Rissoa parvo

0.9

Cerastoderma edule

Montocuta ferruginosa

Mytillus galloprovincialis

Scrobicularia plana

ANOSTRACA

Artemio solina

CIRRIPEDIA

Ballanus perforotus

Chthamalus stellotus

ISOPODA

Cyathura cannoto

Dynamene bidentata

Gnathio vorax

Eurydice pulchro

Eurydice spinigero

Idotea chelipes

Idotea gronulosa

idotea pelogica

jaera forsmani

Sphoeromo hookeri

AMPHIPODA

Amphithoe valido

Amphithoe romondi

Amphithoe rubricato

Bathyporeio sarsi

Corophium insidiosum

Corophium multisetosum

Echinogammorus marinus

196

3.4

5.7

12.6

Echinogommorus stoerensis

Gammarus chevreux

1.4

Gammonus locusto

Haustorius arenarius

Hyale crassipes

Hyale stebbingi

Jassa mamorata

Leptocheirus pilosus

Melita palmato

88.9

951

68.4

Tolorchestio sp

MYSIDACEA

Paramysis helleri

DECAPODA 
Carcinus maenas

Crangon crangon

Pachygrapsus marmoratus

Paloemonetes vanians

INSECTA

Diptero lorvoe

Lepidoptera larvae

PISCES

Blennius sp 1

Blennius sp 2

Pomatoschistus sp
6.6

0.9

4.2

0.5

0.5
13.3

2

0.7

9.1

80

7.6

1.2

2.8

1.8

3.7

1.6
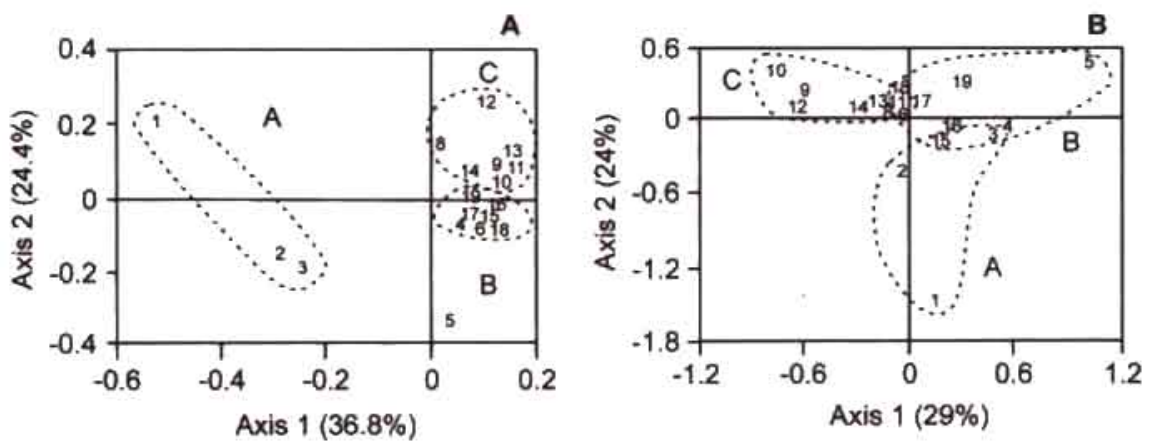

Figure 3. Analysis of hard substrates community structure from PCA of species $X$ stations matrices overlooking species found only once. A - winter situation: Projection of stavons against the first two axis, $r=0.88934$. B - summer situation: Projection of stations against the first two axs, $r=$ 0.85206 . The percentage of variability explained by the principal axis is given. Groups of stations pointed out are discussed in the text.

Hard substrates community

\section{Winter situation}

PCA of species $X$ stations data (figure 3-A) shows a clear separation between stations located near the mouth (group A) and stations located inside the estuary (groups B and C) along the first axis. A separation between stations from the south arm (group C) and stations from the north arm, together with a few stations located near the mouth (group B), is evident along the second axis. Near the mouth, sessile marine species like Chthomalus stellotus and Mytilus galloprovinciairs are very abundant. and significant populations of Montocuta ferruginosa, Idotea pelagica, and Hyole stebbingi, all marine species, together with less important populations of Littorina neritoides, Ballanus perforatus, Idoteo chelipes, I. gronulosa, Jaera forsmani, Amphithoe ramondi, A. rubricato, and Pachygropsus marmoratus are also found. In the inner areas of the estuary. Mytilus galloprovinciolis and Chthamolus stellotus populations become much less 

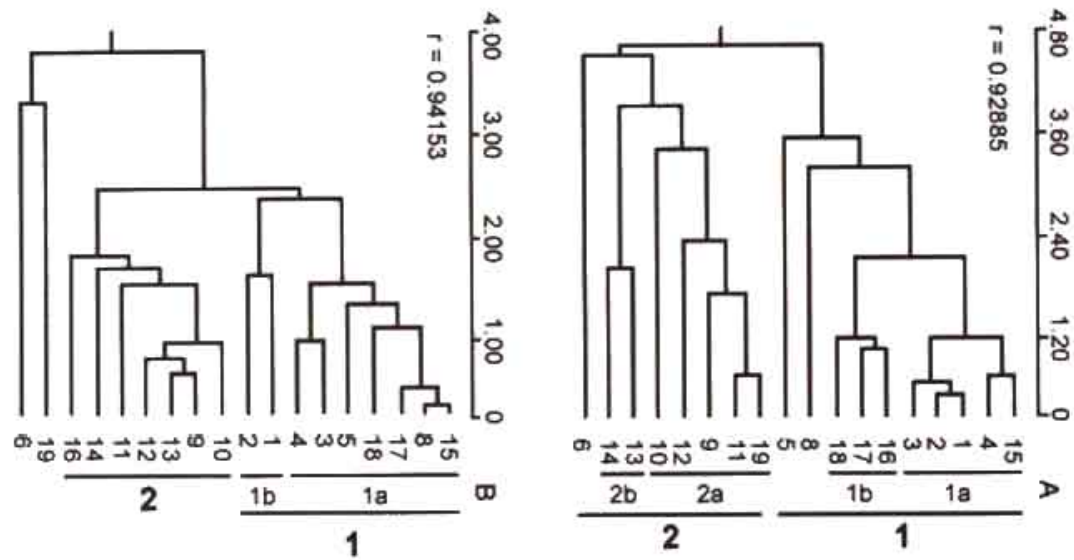

Figure 4. Hard substrates community structure: Cluster analysis of species $X$ stations matrices overlooking species found only once. Data analysed using the Chi-Square distance coefficient ( $Q$ mode analysis) and the UPGMA clustering method. A - winter situation; B - summer situation. Values of cophenetic correlation coefficients are indicated.

abundant, and the presence of other marine species is inconspicuous. Station I, which exhibits the strongest marine influence, (typical estuarine species are represented only by sparse populations of Echinogammarus marinus and Corcinus maenas), presents dense populations of Mytilus golloprovincialis, Chthamalus stellatus, and Hyale stebbingi. The separation of stations from both estuarine arms along the second axis is mainly due to the preferential occurrence of Leptocheirus pilosus and Melita palmata, followed by Sabelloria alveolata, in stations from the north arm, and of Echinogammarus marinus. Sphaeroma hookeri, and Hediste diversicolor (frequently found in sediment deposits over rock), followed by Idoteo chelipes, I. pelagica. Amphithoe ramondi, A. rubricata, and Carcinus moenos, in stations from the south arm.

Station 5. located near the connection of the two arms, appears to be peculiar, exhibiting significant densities of Melita palmato (704 individuals $\left./ \mathrm{m}^{2}\right)$ and Leptocheirus pilosus (437 individuals $/ \mathrm{m}^{2}$ ) populations. Typical estuarine species like Hydrobia ulvoe, Echinogammarus marinus, Sphaeroma hookeri, and Carcinus maenas show higher abundances in the south arm, while Mytilus galloprovincialis and Chthomalus stellatus populations are significant in the north arm (although less abundant than in stations located near the mouth) and very scarce in the south arm.

Cluster analysis of species $X$ stations data (figure $4-A$ ) allows to recognise a structural discontinuity in the communities from both arms and near the mouth. corroborating therefore the results from ordination. Group 1 consists of stations located near the mouth (basically sub-group la) and inside the north arm (sub-group Ib), together with stations 8 and 5, located in the downstream section of the south arm. Group 2 consists primarily of stations from inner areas of the south arm, despite station 19 (upstream section of the north arm) being included in sub-group 2a, and station 6 (near the mouth) is still comprised in the group. 


\section{Summer situation}

PCA of species $X$ stations data (figure 3-B), show an opposition between stations located in the north arm and near the mouth (group B), and stations located in the inner areas of the south arm (group A) along the first axis. Stations from group B are characterised by the presence of several marine species, with a clear dominance of Mytilus golloprovincialis and Chthamolus stellatus, followed by significant populations of Echinogommarus stoerensis, Leptocheirus pilosus, and Melita palmato. Stations located in the south arm present Hydrobia ulvoe and Echinogammarus marinus dense populations, exhibiting also a typical estuarine fauna with regard to other species.

The opposition between stations $\mid$ and 2 (more exposed to marine influence), and the other stations is evident along the second axis. These two stations are characterised by a very strong abundance of Mycilus golloprovincialis and by the occurrence of typical marine species like Hyale stebbingi, Dynamene bidentata, Idotea pelagica, and jaera forsmani. Station 5, like in the winter situation, is found to be peculiar, presenting relatively abundant populations of Leptocheirus pilosus ( 901 individuals $/ \mathrm{m}^{2}$ ) and Melita palmato (267 individuals $/ \mathrm{m}^{2}$ ). It must be emphasised that Echinogommorus moninus shows a quite abundant population all over the estuary in the summer situation.

Cluster analysis of species $X$ stations data (figure 4-B) shows again a discontinuity within the hard substrates community structure in both arms and near the mouth. Group I consists basically of stations located in the north arm and near the mouth despite station 8 (downstream area of the south arm) being comprised in sub-group la. Stations I and 2 (sub-group Ib), located very close to the mouth appear to be distinct from stations inside the north arm (sub-group la). Group 2 consists of all stations from the inner areas of the south arm and station 16 (north arm). Stations 19 and 6 appear as outsiders.

\section{Diversity}

In the winter situation, the Shannon-Wiener index values calculated for each station (table III) demonstrate that the distance relatively to the mouth is not related with a diversity gradient. However, stations from the south arm show higher diversity values than stations located in the north arm and near the mouth, which may be due to the combined effects of tides and stronger freshwater discharge along the north arm, creating a significant daily environmental stress for environmental organisms.

Table III Values of the Shannon-Wiener index calculated for each station in winter and summer situations and for hard and soft substrates communities

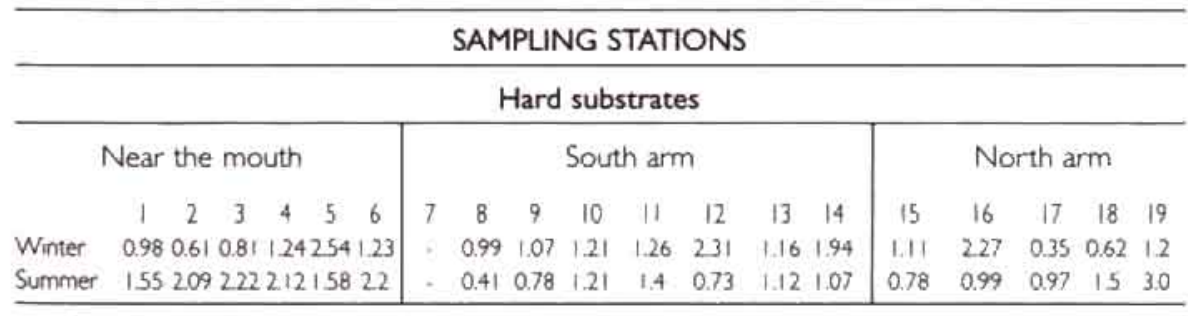


Soft substrates

\begin{tabular}{|c|c|c|c|c|c|c|c|c|c|c|c|c|c|c|c|c|c|c|}
\hline \multicolumn{7}{|c|}{ Near the mouth } & \multicolumn{8}{|c|}{ South arm } & \multicolumn{4}{|c|}{ North arm } \\
\hline & 1 & 2 & 3 & 4 & 5 & 6 & 7 & 8 & 9 & 10 & II & 12 & 13 & 14 & 15 & 16 & 17 & $18 \quad 19$ \\
\hline Winter & 1.0 & 1.39 & - & . & . & 1.52 & 232 & 15 & 2.69 & 219 & 1.96 & 1.43 & 1.91 & 1.71 & 213 & 308 & 1.6 & 2011.52 \\
\hline Summer & 0.92 & 0.76 & - & - & - & . & 265 & 1.83 & 23 & 1.6 & 208 & 1.36 & 1.19 & 1.62 & 151 & 1.45 & 0.66 & 1.380 .54 \\
\hline
\end{tabular}

On the other hand, in the summer situation, the Shannon-Wiener index values calculated for each station (table III) revealed several differences as compared to the winter situation. In the summer, the highest values for diversity are found near the mouth of the estuary, while the lowest values are found inside the south arm.

With regard to hard substrates community, a decrease in diversity was observed in the south arm from winter to summer. while an increase occurred in the north arm and near the mouth. The decrease in diversity observed in the south arm may be explained by the change in biological activity of Echinogammonis morinus, which becomes extremely abundant in the summer situation (average about 3000 individuals $/ \mathrm{m}^{2}$ in the south arm on the Fucus sp. covered areas), affecting species evenness.

\section{Soft substrates community}

\section{Winter situation}

PCA of species $X$ stations data (figure 5-A) shows the opposition between stations 7.9. 10, and II (group A), located in the south arm, corresponding to Spartino maritima and Zostera noltii marshes, and stations without vegetal covered areas (groups $B$ and $C$ ) along the first axis. These stations differ from the others by the fact that several species (e. g. Amage adspersa, Heteromastus filiformis, Hediste diversicolor, Hydrobia ulvoe, Cerostoderma edule, Scrobicularia plana, and Cyathura carinata) present considerably higher population abundances. Along the second axis we can distinguish
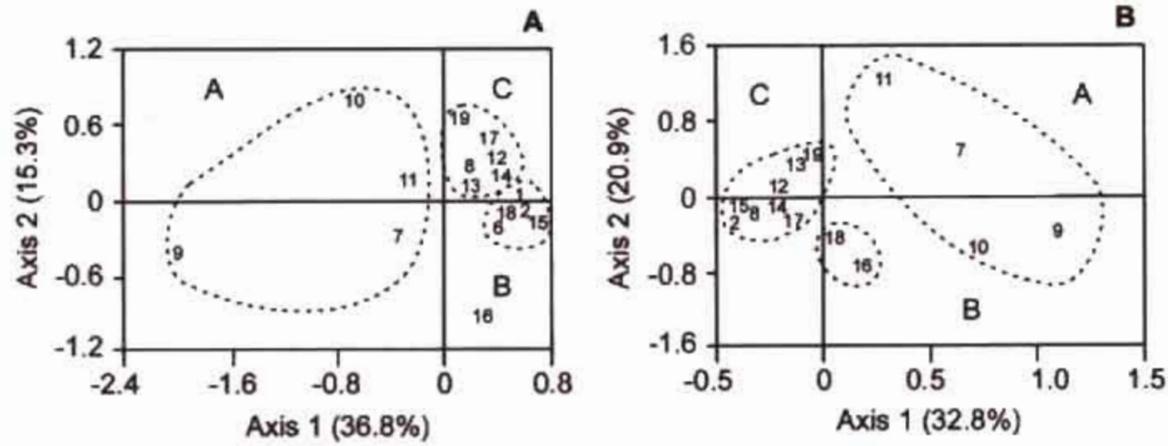

Figure 5. Analysis of soft substrates community structure from PCA of species $X$ stations matrices overlooking species found only once. A - winter situation: Projection of stations against the first two axis, $r=0.80878$. B - summer situation: Projection of stations against the first two axis, $r=$ 0.87681 . The percentage of variability explained by the principal axis is given. Groups of stations pointed out are discussed in the text. 
between stations located in the south arm (8, 12, 13, and 14), followed by stations 17 and 19 (north arm) (group C), and stations located in the north arm and near the mouth of the estuary (group B). Stations from the south arm, even those located in areas without vegetal cover, present higher population abundances than stations from the north arm, namely with regard to common species like Hediste diversicolor, Hydrobia ulvae, Scrobicularia plana, and Cyathura carinata. Station 16, located in the north arm, is clearly separated along the second axis, which is explained by the sporadic occurrence of several rare species in the estuary like Eteone picta, Glycera convoluta, and Spio filicornis.

Cluster analysis of species $X$ stations data (figure 6-A) does not reveal a clear discontinuity within the soft substrates community. Actually, a single main group of stations is recognisable (group 1), consisting of stations from both estuarine arms, while stations 1.2. and 6. located near the mouth appear as outsiders. Nevertheless, stations 9. 11, 10, and 7, located in Spartina maritima and Zostera noltii marshes, are clearly assembled (sub-group Ib), which agrees with results from ordination.
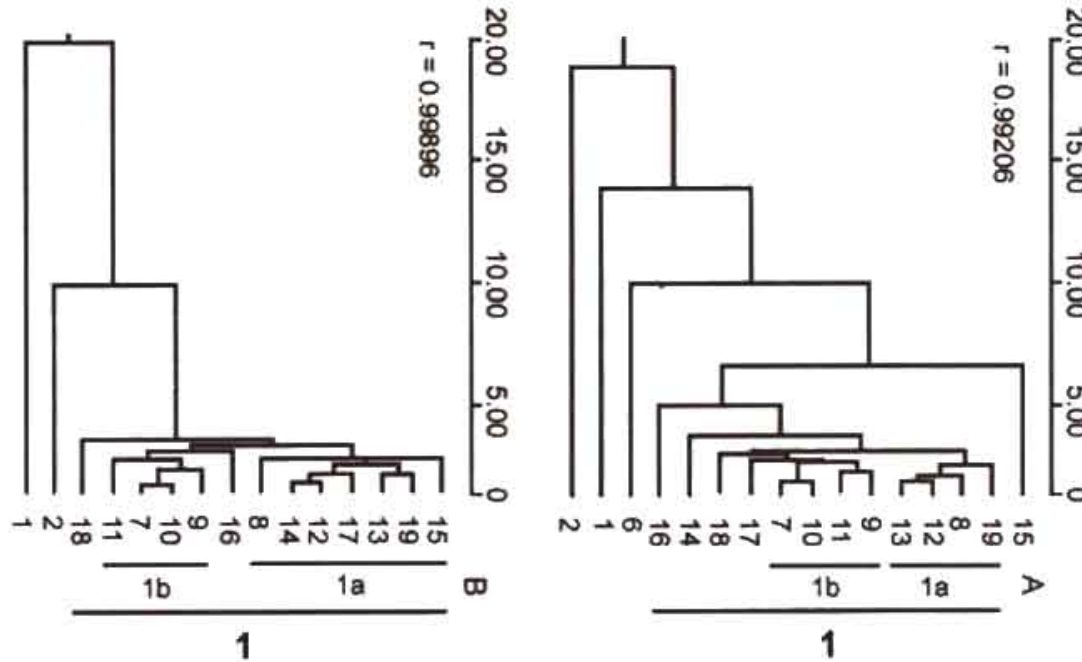

Figure 6. Soft substrates community structure: Cluster analysis of species $X$ stations matrices overiooking species found only once. Data analysed using the Chi-Square distance coefficient $(Q$ mode analysis) and the UPGMA clustenng method A - winter situation: B - summer stuation. Values of cophenetic correlation coefficients are indicated.

Summer situation

PCA of species $X$ stations data (figure 5-B) shows once more the opposition between stations corresponding to Sportino mantima and Zostera nolti marshes (group A) and stations without vegetal covered areas (groups B and C) along the first axis. Like in the winter situation, the most important species contributing to the observed variability are Amage adspersa, Heteromastus filiformis, Hediste diversicolor. Hydrobia ulvae, Cerastoderma edule, Scrobicularia plana and Cyathura corinato (positive side of 
factor 1), which populations are much more abundant in stations from group A as compared to other areas. Contrarily to the winter situation, differences between stations located in the south arm and stations located in the north arm are not evident. This may be due to the increase of marine influence inside the estuary in the summer. determining the occurrence of more uniform conditions.

Cluster analysis of species $X$ stations data (figure $6-B$ ), like in the winter situation, does not bare a discontinuity within the soft substrates community, and again a single group of stations is recognisable (group 1). consisting of stations from both estuarine arms, Stations 1 and 2 located very close to the mouth appear as outsiders. Again like in the winter situation, stations 9, 10,7, and 11, located in Spartina maritima and Zostera noltii marshes, are assembled (sub-group Ib). corroborating results from ordination.

Diversity

The Shannon-Wiener index values calculated for each station in both winter and summer situations (table III) are consistently higher in stations located in Spartina maritima and Zostera noltii marshes, which emphasises their favourable conditions for the development of abundant populations and higher biodiversity. However, differences between other estuarine areas and seasonal variations in diversity are not outstanding.

Physical and chemical parameters

With regard to the winter situation, PCA of water physicochemical factors $X$ stations matrices (figure 7-A) reveals a clear separation between stations from the north and south arms (groups $A$ and $B$ respectively) along the first axis, and a gradient from the mouth (group C) to inner areas of the estuary along the second axis. The variability along the first axis is mainly explained by the distribution pattem of dissolved oxygen and nitrates concentration values (negative side of factor 1), and of salinity and temperature values (positive side of factor 1). Along the second axis, variability is mainly explained by the distribution of salinity, temperature and nitrites values (negative side of factor 2), and of $\mathrm{pH}$ (positive side of factor 2). Actually, it is very clear the opposition along the first axis between stations from the north arm, presenting lower salinities $(20.8 \pm 6.8 \%$ ) (average \pm standard deviation). more stable temperatures ( $12 \pm$ $0.5 \mathrm{oC}$ ), higher concentrations of dissolved oxygen (76.5 $\pm 11.6 \%$ of saturation) and nitrates $\left(0.32 \pm 0.18 \mathrm{mg} . \mathrm{I}^{\prime}\right)$ during low tide, and stations from the south arm, present-

182 ing higher salinities $(22.9 \pm 6.7 \%)$, more variable temperatures $\left(12.9 \pm 2.4^{\circ} \mathrm{C}\right)$. lower dissolved oxygen $(70.6 \pm 7.1 \%)$ and nitrates concentrations $\left(0.16 \pm 0.09 \mathrm{mg} \mathrm{I}^{\prime}{ }^{\prime}\right)$.

These results can be explained taking into consideration the hydraulic circulation in the estuary. In the north arm, the water circulation depends on tides and on the freshwater discharge, determining a faster renewal of the water mass, and consequently higher values of dissolved oxygen. Moreover, since samples were taken during low tide, the river discharge (transporting nutrients from agricultural areas) determined the occurrence of lower salinities and higher nitrate concentrations in the north arm and areas near the mouth. The smaller depth may explain larger 

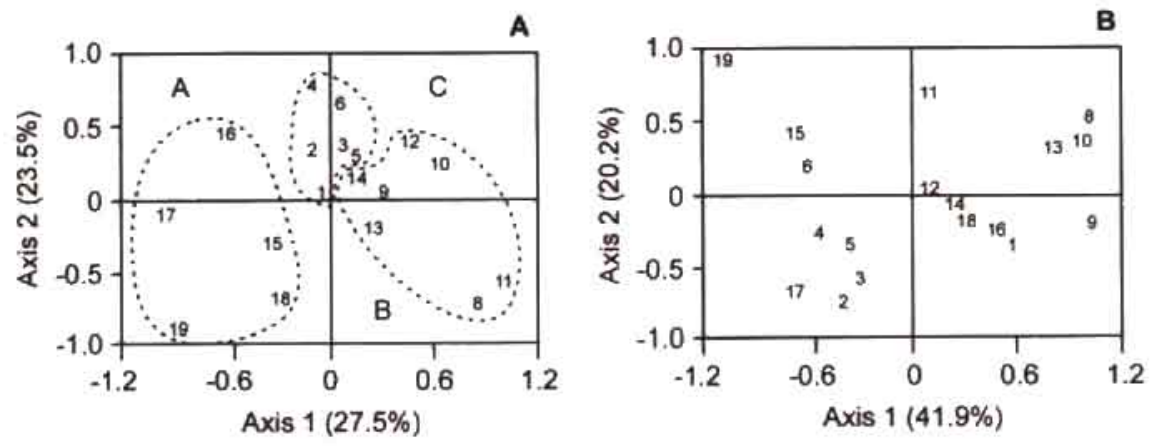

Figure 7. Analysis of phiysicochemical lactors of the water from PCA of factors $X$ stations matnces. A winter situation: Projection of stations aganst the first two axis, $r=0.94057 . B$ - summer situation Projection of stations against the first two axos, $r=0.93314$. The percentage of vanability explained by the principal axus is given. Groups of stations pointed out are discussed in the text.

temperature ranges found in the south arm. Finally, the lower concentration of nitrates in the south arm may be a function of the smaller freshwater discharge.

Due to manne influence, temperature and $\mathrm{pH}$ values $(7.4 \pm 0.4)$ seem to be more uniform near the mouth of the estuary, and nitrite concentration to be low $(0.006 \pm 0.002$ $\left.m g, t^{\prime}\right)$ (probably as a function of stronger oxygenation of the water column).

In the summer situation, the analysis of physicochemical factors of the water does not show conspicuous differences between stations located in both estuarine arms and near the mouth (figure 7-B). Stations 2, 3, 4, 5,6, 15, 17, and 19 (in the north arm and near the mouth) are opposed to stations 1, 8, 9, 10, 11, 12, 13, 14, 16, and 18 (in the north arm, south arm, and near the mouth) along the first axis. The variability along the first axis is mainly explained by lower salinities $(25 \pm 2.1 \%$ ), higher values of dissolved oxygen $(92.8 \pm 6.1 \%), \mathrm{pH}(7.8 \pm 0.3)$ and nitrites $(0.01 \pm 0.002 \mathrm{mg}$. liter-1) found in stations from the negative side of factor I. and by higher salinities $(27.3 \pm 2.4 \%$ ) found in stations from the positive side of factor 1 .

Along the second axis, stations from the inner areas of both arms $(8,10,11,12$. 13. 15, and 19) are partially separated from stations located in the downstream section of the north arm and near the mouth. Temperature is the factor that contributed the most for this partial separation. Actually, the smaller depth as compared to areas near the mouth may explain higher temperatures of the water found in estuarine inner areas.

PCA of water and sediments physicochemical factors $X$ samples matrices shows similar results with regard to winter (figure B-A) and summer (figure 8-B) situations. In both cases, projection of samples against the first two axis of variability allows to consider three distinct equivalent groups. Groups AI and A2 correspond mainly to samples obtained on fine or medium sand bottoms with small organic matter contents ( 0 to $1.5 \%$ ), proceeding from the lower limits of the eulittoral zone (low water level) in the downstream sections of both arms and near the mouth (sand pole). Groups BI, $B 2, C 1$, and $C 2$ correspond to samples from bottoms with large fractions of fine 

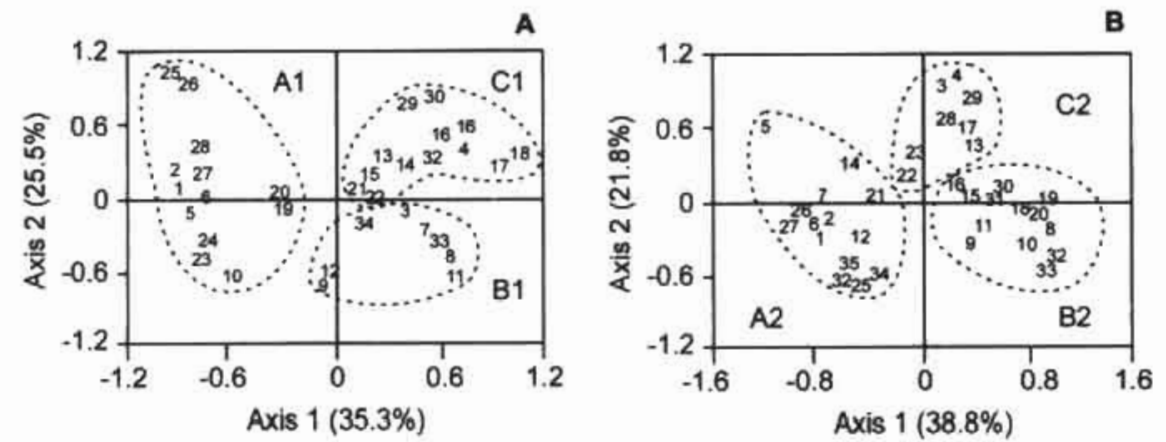

Figure 8. Analysis of physicochemical factors of water and sediments from PCA of factors $X$ samples matrices. A - winter situation; Projection of samples against the first two axs, $r=0.91314, \mathrm{~B}$. summer situation: Projection of samples against the first two axis, $r=0.94261$. The percentage of varability explained by the axos is given. Groups of samples pointed out are discussed in the text.

particles (clay or silt) and higher organic matter contents ( 2 to $4.5 \%$ ), proceeding from the inner areas of both estuarine arms. Groups BI and B2 consist of samples from Spartina maritima and Zostera noltii covered areas in the south arm, characterised by fine sandy mud sediments with high organic matter contents (3.5 to 4.5\%). Groups Cl and $\mathrm{C} 2$ consist essentially of samples from muddy bottoms with no vegetal cover. mainly characterised by clay and silty sediments mixed with medium to coarse sand ( 10 to $40 \%$ ) (originated mainly by dredging activities), and significant organic matter contents ( 2 to $4 \%$ ). Additionally, in the summer situation (figure 8-B) oxygen dissolved levels and salinities are higher in samples from group $C 2$ as compared with samples from group B2.

\section{B - Subridal zone}

52 samples, corresponding to 306 replicates distributed over the year. provided 7554 macrofaunal individuals and allowed the identification of 58 taxa (Table IV).

The relative frequencies of taxa and the average population densities (Table IV) show that only a few species appear consistently well represented through the year. The most frequent and abundant are Amage adspersa, Scrobiculoria plano, and Cyathura

184 carinata but other species are also well represented over the year: Hediste diversicolor, Streblospio shrubsolii, Cerastoderma edule, Hydrobia ulvae. Saduniella losadai. Neomysis integer, and Carcinus muenas.

Higher abundances of Amoge adspersa, Scrobicularia plana, and Cyathura carinato populations (although values are expressed in number of individuals and not biomass, which may introduce a significant bias), suggest that these species play a key role in the ecosystem. However, Scrobicularia plana is primarily represented by juveniles (adults are typical of the intertidal zone), which is probably related to the planktonic larvae colonisation process. 
Table IV List of taxa identified. The number assigned to each taxa correspond to numbers plotted in figures $9-12$. The relative frequencies ( $F$ : number of replicates in which the taxa was found/total number of replicates) and average population density (AD: individuals.m-2 for the total surface of all the samples) found in the Mondego estuary each season are given.

\begin{tabular}{|c|c|c|c|c|c|c|c|c|c|}
\hline & \multirow[b]{2}{*}{ Taxa } & \multicolumn{2}{|c|}{ December } & \multicolumn{2}{|c|}{ March } & \multicolumn{2}{|c|}{ June } & \multicolumn{2}{|c|}{ September } \\
\hline & & $F(\%)$ & $A D$ & $F(\%)$ & $A D$ & $F(\%)$ & $A D$ & $f(\%)$ & $A D$ \\
\hline \multirow[t]{2}{*}{1} & Turbellanid sp & 27 & 05 & 0 & 0 & 0 & 0 & 0 & 0 \\
\hline & Nemertini & & & & & & & & \\
\hline 2 & Oerstedio Sp & 4.1 & 13 & 0 & 0 & 77 & 21 & 0 & 0 \\
\hline 3 & Tetrostemmo sp & 1.4 & 0.3 & 13 & 0.3 & 5.1 & 16 & 4 & 0.9 \\
\hline \multirow[t]{2}{*}{4} & $5 p 1$ & 1.4 & 0.3 & 0 & 0 & 0 & 0 & 0 & 0 \\
\hline & Oligochaeta & & & & & & & & \\
\hline \multirow[t]{2}{*}{5} & $s p 1$ & 6.8 & 1.2 & 0 & 0 & 26 & 0.5 & 27 & 0.8 \\
\hline & Polychaeta & & & & & & & & \\
\hline 6 & Amoge odsperso & 24.7 & 226 & 32.9 & 88.2 & 42.3 & 565 & 37.3 & 138 \\
\hline 7 & Copitella copituto & 1.4 & 0.5 & 26 & 0.5 & 11.5 & 49 & 6.7 & 1.6 \\
\hline 8 & Choetozone setosa & 1.4 & 03 & 13 & 0.3 & 13 & 0.5 & 0 & 0 \\
\hline 9 & Chone collons & 0 & 0 & 0 & 0 & 13 & 54 & 27 & 0.8 \\
\hline 10 & Eteone picto & 2.7 & 0.5 & 0 & 0 & 0 & 0 & 1,3 & 03 \\
\hline 11 & Euldio sp & 1.4 & 0.2 & 0 & 0 & 0 & 0 & 0 & 0 \\
\hline 12 & Ghcera convoluto & 0 & 0 & 0 & 0 & 0 & 0 & 4 & 0.8 \\
\hline 13 & Hediste diverscolor & 13.7 & 3.4 & 6.6 & 21 & 7.7 & 4.7 & 10.7 & 30.3 \\
\hline 14 & Heteromostus filformis & 1.4 & 0.9 & 5.3 & 1 & 3.8 & 1.6 & 4 & 0.8 \\
\hline 15 & Loxs koren & 0 & 0 & 0 & 0 & 0 & 0 & 1.3 & 0.3 \\
\hline 16 & Negnthes succineo & 0 & 0 & 1.3 & 0.3 & 0 & 0 & 0 & 0 \\
\hline 17 & Nephtys arroso & 27 & 1.3 & 0 & 0 & 13 & 0.3 & 5.3 & 15 \\
\hline 18 & Nephtys hombergi & 1.4 & 0.3 & 0 & 0 & 0 & 0 & 1.3 & 0.3 \\
\hline 19 & Nephas tongosetoso & 1.4 & 0.3 & 0 & 0 & 0 & 0 & 0 & 0 \\
\hline 20 & Nephtys parodoxa & 27 & 1.0 & 0 & 0 & 1.3 & 0.3 & 0 & 0 \\
\hline 21 & Penneres cultufera & 0 & 0 & 0 & 0 & 0 & 0 & 1.3 & 0.3 \\
\hline 22 & Pohdoro cilota & 4.1 & 0.9 & 13 & 1.8 & 34.6 & 550 & 8 & 23 \\
\hline 23 & Onopsis sp Speo decorvtus & 0 & 0 & 0 & 0 & 1.3 & 0.3 & 0 & 0 \\
\hline 24 & Spro decorotus & 0 & 0 & 0 & 0 & 3.8 & 1.3 & 6.7 & 26 \\
\hline \multirow[t]{3}{*}{25} & Streblospio shrubsoli & 11 & 129 & 25 & 31.8 & 35,9 & 195 & 38.7 & 38.9 \\
\hline & Mollusca & & & & & & & & \\
\hline & Bivalvia & & & & & & & & \\
\hline 26 & Abro nutida & 0 & 0 & 0 & 0 & 0 & 0 & 27 & 1 \\
\hline 27 & Cenostaderma exdule & 5.5 & 1.5 & 0 & 0 & 16.7 & 5.4 & 33.3 & 50.2 \\
\hline 28 & Scrobroulono plana & 425 & 147 & 34.2 & 103 & 24,4 & 10.3 & 52 & 889 \\
\hline 29 & Solen morprontus & 0 & 0 & 0 & 0 & 0 & 0 & 27 & 05 \\
\hline 30 & Sprsula suberuncoto & 0 & 0 & 0 & 0 & 1.3 & 1.6 & 1.3 & 0.3 \\
\hline 31 & Sprsulla elliptica & 14 & 0.5 & 0 & 0 & 0 & 0 & 0 & 0 \\
\hline \multirow[t]{2}{*}{32} & Telling tervurs & 6.8 & 2.1 & 0 & 0 & 0 & 0 & 6.7 & 44 \\
\hline & Gastropoda & & & & & & & & \\
\hline 33 & Hrdrobio ulvoe & 8.2 & 27 & 118 & 7.8 & 43.6 & 37.2 & 33.3 & 143 \\
\hline \multirow[t]{2}{*}{34} & Nassonus rebculons & 1.4 & 0.2 & 0 & 0 & 0 & 0 & 0 & 0 \\
\hline & isopoda & & & & & & & & \\
\hline 35 & Cyothum connato & 41.6 & 55.6 & 39.5 & 414 & 33.3 & 35.9 & 493 & 59.1 \\
\hline 36 & Eurydice pulchro & 12 & 0.2 & 0 & 0 & 0 & 0 & 0 & 0 \\
\hline 37 & Idotec chelipes & 0 & 0 & 0 & 0 & 1.3 & 0.3 & 1.3 & 03 \\
\hline 38 & Parognathin formuco & 0 & 0 & 0 & 0 & 0 & 0 & 1.3 & 03 \\
\hline 39 & Sodunello losodai & 6.8 & 18 & 1.3 & 0.3 & 9 & 5.4 & 6.7 & 4.3 \\
\hline \multirow[t]{2}{*}{40} & Sphoeroma hooken & 5.5 & 27 & 0 & 0 & 6.4 & 1,3 & 10.7 & 3.2 \\
\hline & Amphipoda & & & & & & & & \\
\hline 41 & Bothyporeng sars & 41 & 3.1 & 0 & 0 & 77 & 23 & 27 & 13 \\
\hline 42 & Conophium mulusetosum & 27 & 0.6 & 0 & 0 & 1.3 & 0.3 & 2.7 & 16 \\
\hline 43 & Houstonius arenarius & 0 & 0 & 1.3 & 0.3 & 0 & 0 & 0 & 0 \\
\hline
\end{tabular}




\begin{tabular}{|c|c|c|c|c|c|c|c|c|c|}
\hline 44 & Melito polmoto & 1.4 & 0.2 & 0 & 0 & 7.7 & 5.6 & 107 & 26 \\
\hline & Cumacea & & & & & & & & \\
\hline \multirow[t]{2}{*}{4} & Eocumo dollfuss & 0 & 0 & 0 & 0 & 13 & 0.3 & 0 & 0 \\
\hline & Mysidacea & & & & & & & & \\
\hline 46 & Mesopodopsis slobiberi & 0 & 0 & 0 & 0 & 1,3 & 0.3 & 0 & 0 \\
\hline \multirow[t]{2}{*}{ 47 } & Neomysis integer & 16.4 & 43 & 11.8 & 172 & 26 & 0.5 & 13 & 0.3 \\
\hline & Decapoda & & & & & & & & \\
\hline 48 & Carcinus moengs & 5.5 & 1 & 39 & 0.8 & 6.4 & 1,3 & 6.7 & 1.7 \\
\hline 49 & Crongon congon & 0 & 0 & 0 & 0 & 103 & 26 & 133 & 3.8 \\
\hline \multirow[t]{2}{*}{50} & Paloemonetes varians & 0 & 0 & 0 & 0 & 13 & 0.5 & 0 & 0 \\
\hline & Echinodermata & & & & & & & & \\
\hline 51 & Morthosterios gloaghs & 1.4 & 0.2 & 0 & 0 & 0 & 0 & 0 & 0 \\
\hline \multirow[t]{2}{*}{52} & Ophrumosted sp & 1,4 & 0.2 & 0 & 0 & 0 & 0 & 0 & 0 \\
\hline & Insecta & & & & & & & & \\
\hline 53 & Chironorninge larvoe & 27 & 0.5 & 0 & 0 & 3.8 & 26 & 13 & 1 \\
\hline \multirow[t]{3}{*}{54} & Duptero lorvoe & 0 & 0 & 0 & 0 & 0 & 0 & 4 & 1 \\
\hline & Gomphus pulchellus & 1.4 & 0.3 & 0 & 0 & 0 & 0 & 0 & 0 \\
\hline & Pisces & & & & & & & & \\
\hline$\$ 5$ & Ammodres tobionus & 0 & 0 & 1.3 & 0.3 & 0 & 0 & 0 & 0 \\
\hline 56 & Engroulis encrasicolus & 1.4 & 0.3 & 0 & 0 & 0 & 0 & 0 & 0 \\
\hline 57 & Platichichys flesus & 0 & 0 & 0 & 0 & 0 & 0 & 13 & 0.3 \\
\hline
\end{tabular}

\section{Seasonal variation of community structure}

A seasonal variation of the total macrofaunal abundance was observed, with the lowest values for total macrofaunal abundance being found in December ( 972 individuals of 38 species were collected). Until March, although total macrofaunal abundance increased ( 1556 individuals were collected), the number of species found was much lower (only 17), probably as a repercussion of the effects of winter. From March to June, the spring influence was clearly discernible in the increase of total macrofaunal abundance and number of species (2981 individuals of 33 species were collected). Finally, from June to September, a small decrease in total macrofaunal abundance was observed (2045 individuals collected), although the number of species collected (37) was slightly higher.

The analysis of matrices of taxa $X$ stations revealed clear differences between the macrofaunal community structure of the two arms of the estuary. Projection against the first and second axis of variability, based on December, March, June, and September data (figures 9: A, 10: A, 11: $\mathrm{A}$, and 12: A), and despite seasonal variations, show a consistent pattern of structural discontinuity between stations D. E. F, G. and H. located in the inner areas of the south arm, and stations J, K, L, and M, located in the middle and upstream sections of the north arm.

186 Station A, located close to the mouth of the estuary, stations B and C. located in the downstream area of the south arm, and station I, located in the downstream section of the north arm, appear to be structurally more similar to each other, although seasonal variability in the macrofauna composition seems to be stronger, which can explain their irregular pattern of assemblage through the year. On the other hand, stations located in the upstream section of the north arm $(L$ and $M)$ appear to be relatively different from other stations in the north arm with regard to macrofauna, which is particularly evident in March situation (figure 10:A). where these two stations are clearly separated from the rest. 

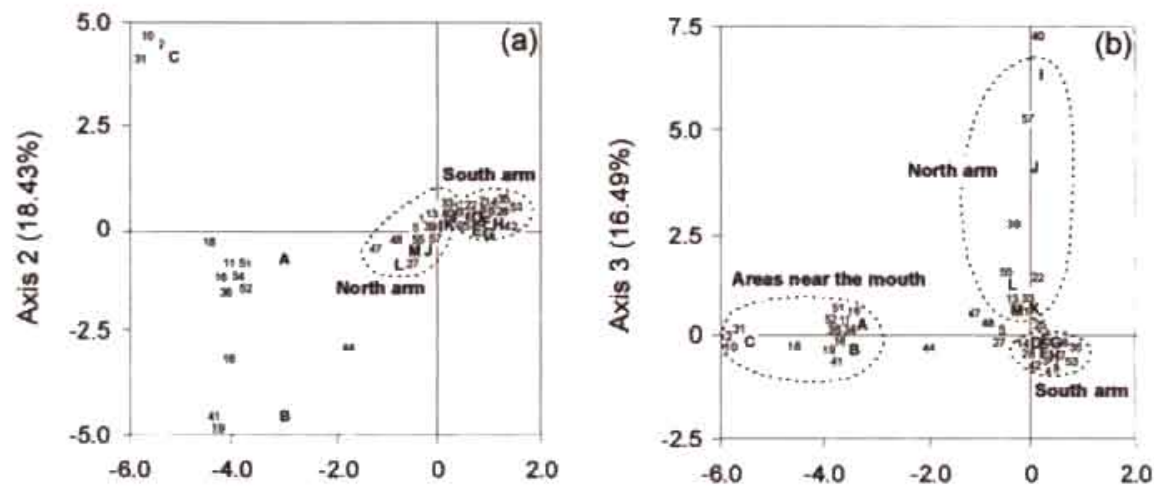

Figure 9. December situatuon: Results from Cornespondence Analysis of benthic macrofaunal data Projectoon of stations ( $A$ to $M$ ) and taxa (corresponding to numbers assigned in table 2) against the first and second $(A)$ and first and third $(B)$ axis of vanability. The percentage of variability associated wrth each axis in indicated in parentheses.
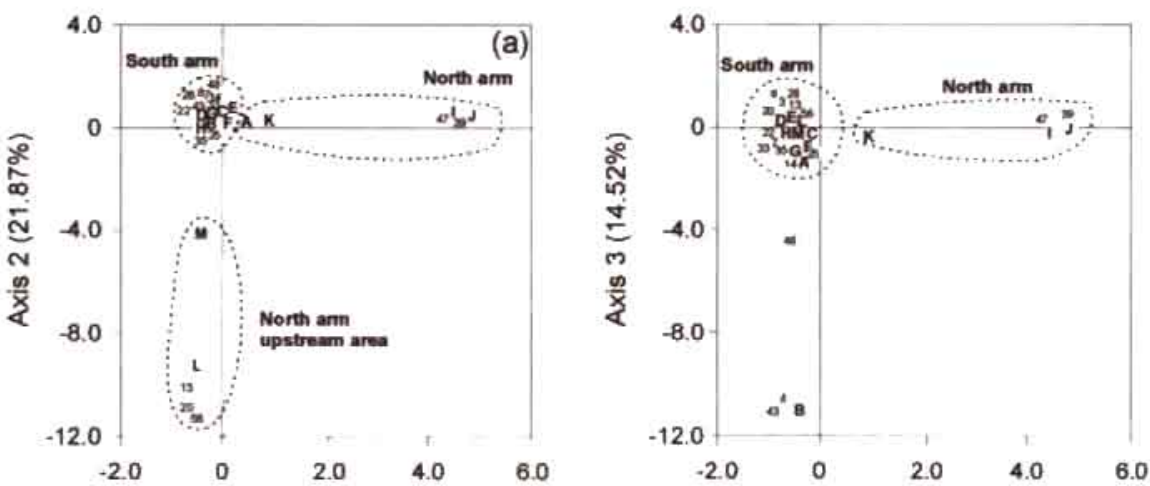

Figure 10. March situation: Results from Correspondence Analysis of benthic macrofaunal data. Projection of stations ( $A$ to $M$ ) and taxa (corresponding to numbers assigned in table 2) against the first and second (A) and first and third (B) axis of variability. The percentage of variability associated with each axis in indicated in parentheses.

Projection against the first and third axis of variability (figures 9. B, 10: B, II: B, and $12: B$ ) reveals a roughly comparable structural organisation, showing nevertheless more clearly the higher similarity between stations located closer to the mouth, with the exceptions of station I in December and station B in March.

Stations from the inner areas of the south arm (D. E. F, G, and H) are mainly characterised by the occurrence of abundant populations of Amage adspersa, Scrobiculano plana, and Cyathura corinata, true estuarine species, followed by more sparse populations of Capitella capitota, Heteromastus filiformis, and Polydora ciliata, and depending on the time of the year, by the less frequent or occasional occurrence of 
other species, like Tetrastemma sp. and other nemertines, oligochaetes, Chaetozone setosa, Chone colloris, Oriopsis sp., Spio decoratus, Streblospio shrubsolii. Hydrobia ulvae. Idotea chelipes, Corophium multisetosum. Haustonus arenarius, and tolerant Chironominae and Diptero larvoe.
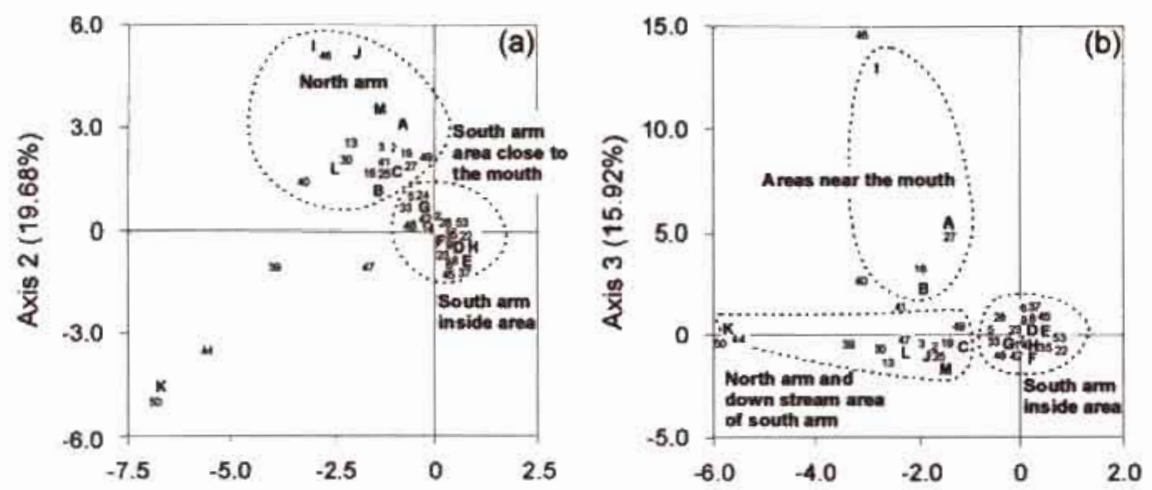

Figure 11. June situation: Results from Correspondence Analysis of benthic macrofaunal data Projection of stations ( $A$ to $M$ ) and taxa (corresponding to numbers assigned in table 2) against the first and second (A) and first and third (B) axis of variability. The percentage of variability associated with each axis in indicated in parentheses.
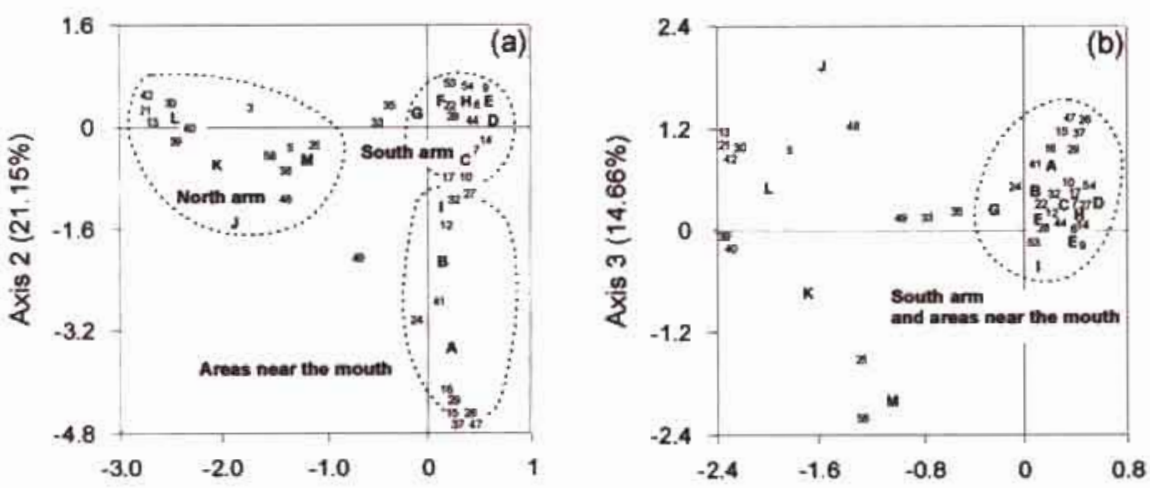

Figure 12. September situation: Results from Correspondence Analysis of benthic macrofaunal data. Projection of stations ( $A$ to $M$ ) and taxa (corresponding to numbers assigned in table 2 ) against the first and second (A) and first and third (B) axis of variability. The percentage of variability associated with each axis in indicated in parentheses.

Stations located along the north arm (J. K, L, and M), which present an impoverishment of the benthic populations, are mainly characterised by the presence of sparse populations of Hediste diversicolor. Soduriella losodai, Sphaeroma hookeri, and Neomysis integer. Through the year other species can be found more or less sporadically in these stations, like turbellarians, Oerstedia sp., Tetrastemma sp., oligochaetes, Nephthys paradoxa, Perinereis cultrifera, Streblospio shrubsolii, Cerastoderma edule. Hydrobio ulvae, Spisula subtruncata, Paragnathia formica, Bathyporeia sarsi, 
Corophium multisetosum, Melita polmata, Mesopodopsis slabberi, Corcinus maenas, Crangon crangon, Paloemonetes varians, Gomphus pulchellus, Ammodytes tobianus, and Platichtys flesus. The presence of infaunal species, like Hediste diversicolor or Streblospio shrubsolii is nevertheless almost limited to stations $L$ and $M$, located in the upstream section of the north arm. On the other hand, the occurrence of Gomphus pulchellus (a freshwater insect) in station $M$ in December was surely related to the river freshwater discharge.

Finally, stations located closer to the mouth (A, B, C, and I). despite strong seasonal variations in macrofaunal composition, can be primarily characterised by the presence of sparse populations of Cerostoderma edule and Bathyporeia sarsi, followed by the irregular or sporadic occurrence of Oerstedia sp., Eteone picto, Eulalia sp., Glycera convoluta, Lagis koreni, Nephthys spp., Nereis succinea, Spio decoratus, Streblospio shrubsolii, Abra nitida, Nossarius reticulatus, Solen marginatus, Spisula eliptica, Tellina tenuis, Eurydice pulchra, Idotea chelipes, Saduriella losadai. Sphaeroma hookeri. Neomysis integer, Marthostenas glacialis, and ophiuroids, which obviously reflects a stronger marine influence.

Influence of environmental factors on biodiversity and total macrofauna abundance

In order to understand the influence of physicochemical factors on the macrofauna distribution it was firstly necessary to characterise the estuary with regard to these factors.

PCA of matrices of physicochemical factors $X$ sampling stations (figure 13) also reveal a consistent pattern over the year. From the projection against the first two axis of variability, stations appear distributed along a physical and chemical gradient, with stations located in the downstream areas of the north arm in one of the edges, stations located in the upstream section of the north arm and downstream areas of the south one in the middle, and stations located in the inner areas of the south arm in the other edge. This is clearly the situation in December (figure 13: A) and june (figure 13: C). while in March and September (figure 13: B and 13: D) station A, located near the mouth, appears to be separated.

Stations from inner areas of the south arm (D, E, F, G. and $H)$ and stations from the downstream areas of the south arm, north arm and from near the mouth $(A, B, C$, I. J, K, L, and M) are almost always opposed along the first axis of variability. Stations located in the inner area of the south arm are mainly characterised by more fine sediments, with larger fractions of fine sand to clay, higher organic matter (from 3.2\% in station D to $9 \%$ in station $G$ ) and carbonate contents (from $3.3 \%$ in station D to $8.7 \%$ in station G) and, in December, higher nitrite concentrations in the water column (from $1.28 \mathrm{mg}^{\prime \prime}{ }^{\prime \prime}$ in station D to $2.07 \mathrm{mg} . \mathrm{I}^{\prime}$ in station F). Stations located in downstream areas of the south arm, along the north arm, and near the mouth are mainly characterised by more coarse sediments, which tend to present larger fractions of gravel and coarse to medium sand, while the water column tends to present higher salinities (during high water), higher dissolved oxygen levels (the minimum observed was $86 \%$ of saturation in station A in March) and, in December, higher pH (from 6.7 in station $A$ to 8 in station $M$ ). 

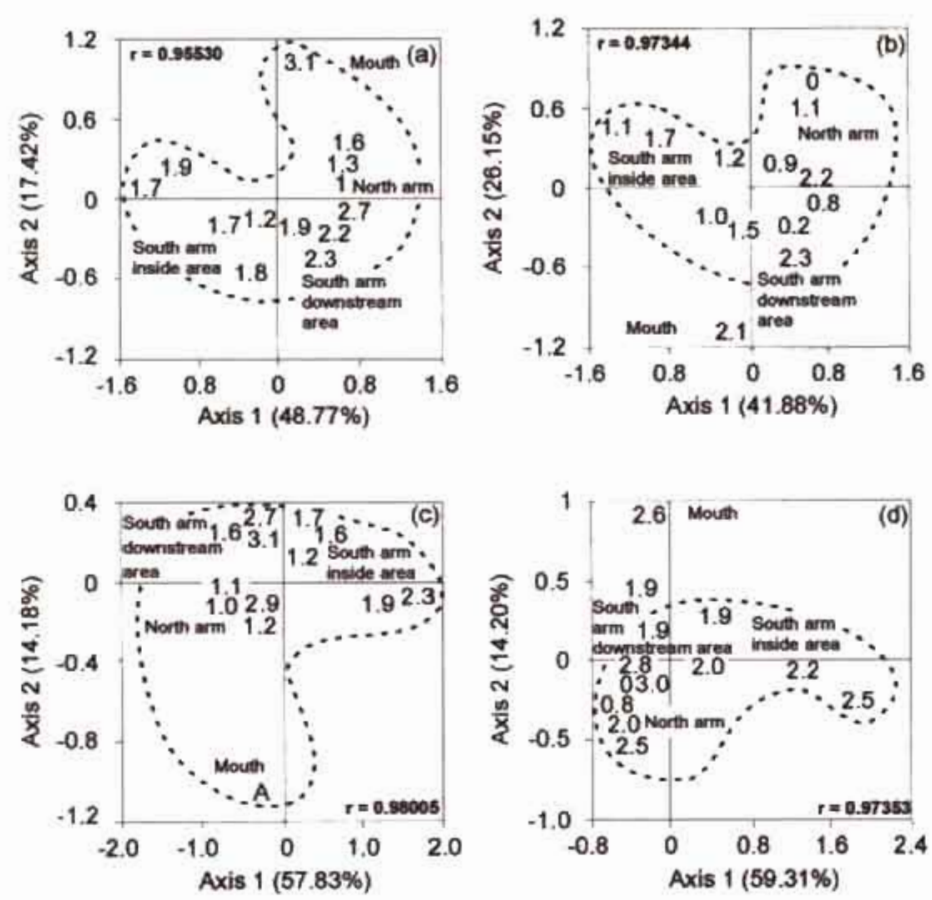

Figure 13. Results from PCA of physicochemical data of water and sediments. Projectron of stations against the first two axis of variability A - December: B - Manch. C - June: D - September The percentage of vanability associated with each axis in indicated in parentheses.

Along the second axis of variability station A, located near the mouth of the estuary, is opposed to the other stations, especially as a function of the characteristics of the water column, reflecting also the seasonal variations, In relation to water factors. resemblance between stations located inside both estuarine arms and station $A$, located close to the mouth, clearly changes trough the year. It is nevertheless impossible to go further in the analysis of the seasonal variation of water factors, because it depends on changes in the river freshwater discharge and on water circulation. Since the available data are prompt measures, they cannot be considered very significant. Nevertheless, closer to the mouth of the estuary salinity tends to be higher, which is normal, as well as dissolved oxygen levels, while in the inner areas temperature tends to be higher, as well as nitrogen concentrations.

The projection of the Shannon-Wiener index values, seasonally calculated for each station, over the ordination obtained from PCA of matrices of physicochemical factors $X$ stations (figure 14 ), show a roughly regular pattern for the distribution of diversity values through the year. Despite seasonal variations, biodiversity tends to reach the highest values near the mouth and in the downstream area of the south arm, remaining approximately stable with relatively high values in the inner areas of the south arm. On the contrary, strong seasonal changes in biodiversity are evident in the north arm, although there is a certain pattern over the year. Diversity values tend to 

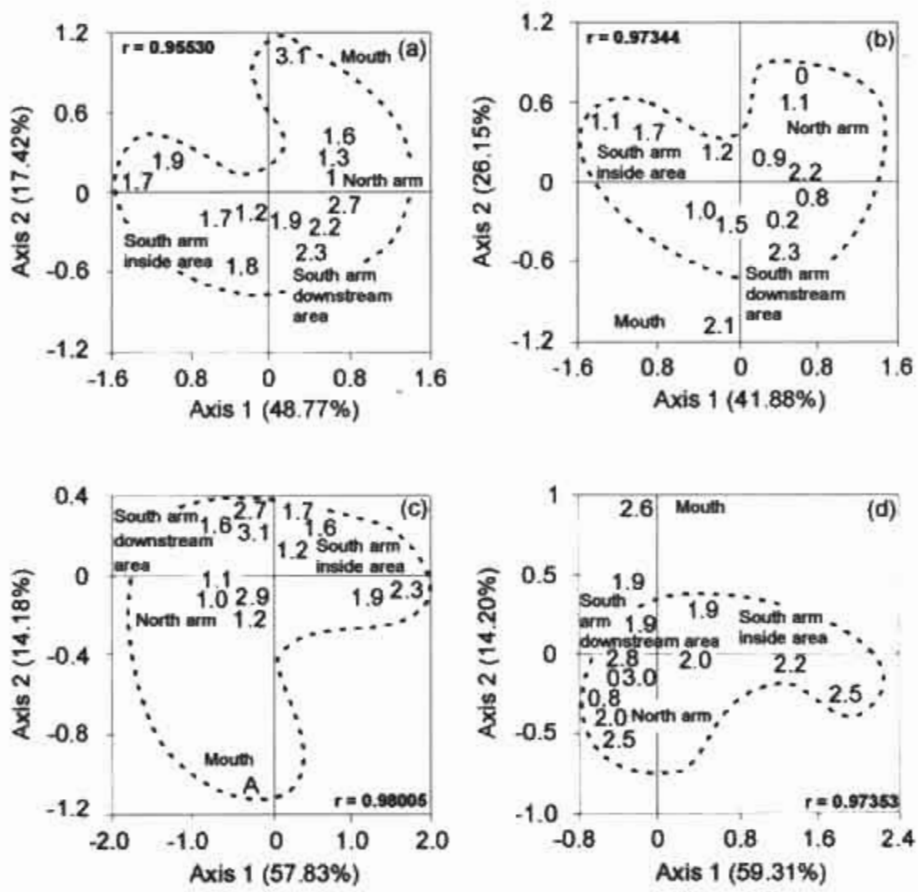

Figure 14. Plot of the Shannon-Wiener index values, calculated for each station in each time of the year, over the projection of stations against the first two axis of varability, obtained from PCA of physicochemical data of water and sediments: A - December: B - March; C - June: D - September. The percentage of variability associated with each axis in indicated in parentheses.

be higher closer to the mouth, decreases in the middle section of the north arm, and increases again in the upstream section.

With regard to total macrofauna abundance (individuals. $\mathrm{m}^{2}$ ). despite seasonal variations and the bias introduced by the sampling method, a pattern of distribution through the year is also recognisable (figure 15). Macrofauna is consistently more abundant in the inner areas of the south arm, although in the Pranto river values are comparatively lower (figure 15). and also significantly elevated in the downstream area of the south arm and upstream section of the north arm. In the north arm, there is a clear rarefaction of macrofauna from the upstream areas to the mouth. which is particularly evident in the middle section.

Summarising, it is possible to distinguish several areas in the estuary with regard to biodiversity and total macrofauna abundance:

Stations from the inner areas of the south arm. characterised by fine sediments, richer in organic matter and carbonate contents, and by higher concentrations of nitrogen in the water column, present a relatively stable and high biodiversity and by far the highest macrofauna abundances.

Comparatively, the downstream area of the south arm, characterised by sediments with significant fractions of coarse to medium sand, more poor in organic 


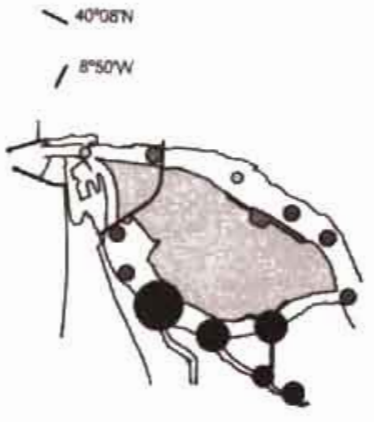

(a)

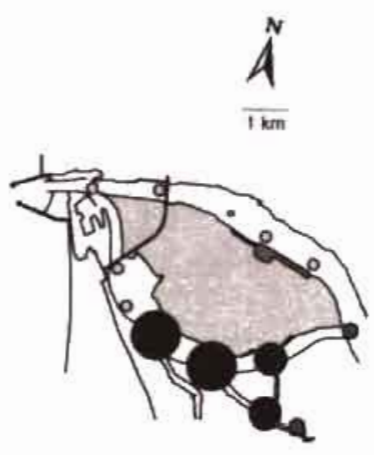

(b)

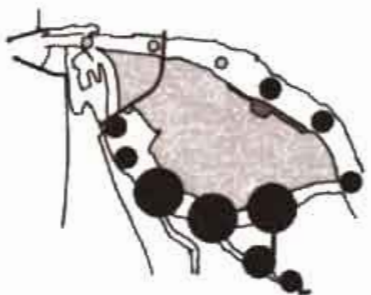

(c)

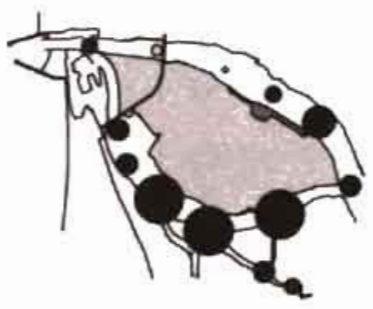

(d)

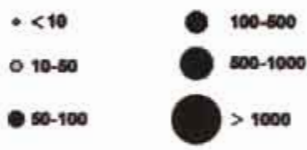

Figure 15. Spatial and temporal variation of total macrofauna abundance (individuals.m-2) in the Mondego estuary: A - December; B - March; C - June: D - September.

192 matter and carbonate contents, and by higher salinities and dissolved oxygen levels, presents an higher biodiversity but a lower macrofauna abundance.

Areas near the mouth and along the north arm are characterised by sandy bottoms, poor in organic matter and carbonate contents, although the fine sand fraction is more important near the mouth and in the upstream section, while the gravel to medium sand fractions are predominant in the middle section. Salinities and dissolved oxygen levels are also consistently higher along the north arm, although salinity tends to decrease from the mouth to the upstream areas. However, due to tidal currents and freshwater discharge, daily salinity fluctuations are by far more significant 
in the north arm (Marques 1989), especially in rainy periods. Near the mouth, biodiversity presents regularly the highest values found in the estuary, while the lowest ones and the strongest changes over the year occur in the north arm, particularly in the middle section. Total macrofaunal abundance is low along the north arm, with the exception of its upstream section, and therefore the middle section of the north arm constitutes the poorest area in the estuary for both biodiversity and macrofaunal abundance.

\section{Discussion}

\section{Intertidal zone}

The analysis of both hard and soft substrates communities structure showed clear differences between the two arms of the Mondego estuary, namely with regard to populations abundance and biodiversity. In both cases a good agreement was found between results from the analysis of biological and physicochemical data.

The observed differences are most probably due to very dissimilar hydrographic characteristics of the two arms. The south arm is still less affected by human activities and presents more favourable environmental conditions for the development of enhanced populations of true estuarine species. Nevertheless, the south arm is also shallower than the north arm, and water circulation depends widely on tides, especially in the summer. For these reasons, we consider that the south arm appears potentially much more exposed to environmental changes.

Salinity appears to be the most important factor controlling the hard substrates community structure, while sediments granulometry is the most important factor controlling the distributional ecology of soft substrates macrofauna, followed by organic matter contents, salinity, and dissolved oxygen. Other studied factors seem to play a less important role with regard to macrofauna distribution.

Spartina maritima and Zostera noltii marshes appear to be the richest areas with regard to macrofauna abundance and biodiversity. However, occasional blooms of Enteromorpho spp. have been observed in the south arm, probably as a function of excessive nutrients release into the estuary. Since macrophytes have roots and are only able to take up nutrients from the sediments, it seems possible that macroalgae like Enteromorpho, which is able to take up nutrients directly from the water, can take advantage from this situation. Therefore, it seems also likely that an eutrophication process might take place in the south arm, and in such a case a shift in the benthic primary producers could occur, affecting the structure and functioning of the trophic chain and ultimately the species composition in the community.

\section{Subtidal zone}

The subtidal benthic macrofauna of the Mondego estuary appears to be clearly impoverished. The Mira estuary, located in the Portuguese southwest coast, which is 
approximately identical to the Mondego in size, have been considered as relatively unaffected by human impacts, and can therefore provide a reasonable basis for comparison. Moreover, data on the Mira estuary (Andrade 1986) was collected according to a relatively similar sampling strategy and using identical sampling devices. With regard to subtidal benthic organisms, 151 taxa were identified for the Mira, while only 58 (about 38\%) were identified for the Mondego. Furthermore, only 21 species were found in both estuaries, which appear to indicate a considerable contrast in the species composition. Differences observed with regard to total macrofaunal abundance were not so important (an average of 624 individuals. $\mathrm{m}^{2}$ per sample in the Mira, and 466 individuals. $\mathrm{m}^{2}$ per sample in the Mondego). Despite any conceivable bias in sampling, the observed differences must be considered highly significant.

The analysis of benthic macrofauna community structure through the year shows that. biologically, the two arms of the Mondego estuary constitute different subsystems. This structural discontinuity is quite obvious between the inside areas of both arms, although closer to the mouth, due to the marine influence, differences become less apparent. This fits well with results from the independent analysis of environmental factors, and additionally the present results are consistent with those from the study on the intertidal communities. With regard to the community structure, biodiversity, and total macrofaunal abundance it is therefore possible to recognise different estuarine areas in relation to physicochemical environmental factors, respectively the inner areas of the south arm, the mouth of the estuary and downstream areas of both arms. and the middle and upstream sections of the north arm.

Since the water circulation in the south arm is mostly dependent on tides, current velocities are inferior and conditions are more favourable to fine particles and organic matter deposition (McLusky 1989). This tends to bring about a biological improvement, since subtidal fauna usually depends on sediments stability and organic matter contents (Gould et al. 1987). This can explain the relatively high and stable biodiversity values found through the year, and the higher abundances for total macrofauna, as observed in the inner areas of the south arm.

On the contrary, current velocities are higher along the north arm. due to both the river discharge (during low water) and a fast tidal penetration. This can explain the change in bottom characteristics, and although the species-sediment relationship is not always a simple linear function of grain size and organic matter contents (Jones et al. 1986), this bottom change is certainly one of the most important reasons for biological differences observed between both estuarine arms. Additionally, due to the river discharge and strong tidal current, daily salinity fluctuations in the north arm are higher than in the south arm (Marques 1989), which is probably a second major cause of faunal impoverishment (Barr et al. 1990). This agrees with the direct relationship between faunal type and tidal stress, as observed by Warwick and Uncles (1980).

The granulometric structure of the inhabitat and salinity fluctuations seems therefore to be the most important factors conditioning the subtidal macrofauna distribution in the Mondego estuary.

On the other hand, infaunal species are dominant in the south arm, especially in the inner areas (e.g. Amoge adspersa, Copitella capitato, Heteromastus filiformis, Polydora 
ciliata, and Scrobiculario plana), while a clear dominance of epifaunal species (e. g. Saduriello losadai, Sphoeroma hookeri, Neomysis integer, and Corcinus maenas) is evident in the north one. This is probably related with shifting sediments, caused by a faster water circulation, which tend to prevent the colonisation and long-term establishment of a permanent infauna, determining the occurrence of typically sparse benthic communities. mainly constituted by mobile epibenthic species (Barr et al. 1990). Nevertheless, in the upstream section of the north arm, where dredging operations do not take place, infaunal species (e. g. Hediste diversicolor and Streblospio shrubsolii) can be found through the year. It appears therefore that the strong changes in biodiversity and the extreme macrofaunal impoverishment in the middle section of the north arm are also a function of regular dredging. Actually, dominant species decimation following disturbance of the bottom as been observed in other case studies. In Long Island Sound, for instance, polychaete populations of Nephthys strongly decreased at or near the disturbance site, although little or no effects on the populations were detected at more than $400 \mathrm{~m}$ from the impacted area (Zajac and Whitlatch 1988).

It has been observed that the recovery of dredged zones in number of species is practically obtained six months after the completion of dredging operations, although biomass takes longer to reach values similar to those found in unaffected areas (LópezJamar and Mejuto 1988). In the Mondego estuary, time intervals between dredgings (approximately twice a year) are likely to be too short, and do not allow macrofauna recovery, which surely contributes to the obvious instability of the north arm community. However, there are no other indications on the effects of dredging besides the absence of infaunal species and macrofaunal impoverishment.

\section{Conclusions}

The Mondego estuary is under severe environmental stress, and it is difficult to establish the benthic community temporal trends and if the ongoing changes are reversible. The benthic communities in estuarine environments are generally characterised by wide fluctuations in the abundance of constituent species, although they present a more persistent qualitative composition (Boesch et al. 1976). Moreover. benthic organisms, namely infauna, are especially important components in estuarine ecosystems, because most of them have limited mobility and respond to environmental stress (Bilyard 1987). It seems therefore necessary to monitor the Mondego estuary communities, probably with emphasis on benthic macrofauna, although such studies need labour-intensive sample sorting and taxonomy. This monitoring study should take all species into consideration, once using only the most abundant ones for characterising communities, or as indicators of physicochemical conditions, may be unreliable because of variation in both time and space in dominant species, and the lack of stress-response knowledge for local species (Jones 1990). It will provide valuable information that cannot otherwise be obtained, since the dynamics of estuarine benthos is very complex and strongly limits the usefulness of short-term baseline and impact studies. 


\section{Acknowledgements}

The present paper was supported by FCT (Portuguese National Foundation for Science and Technology). The authors are indebted to all the colleagues from the University of Coimbra who assisted in field and laboratory work

\section{References}

Almeida. A. J. T., 1988. Estrutura, dinåmica e produçāo da macrofauna acompanhante dos povoamentos de Zostera noltii e Zostera marina do estuáno do nio Mira. Tese de doutoramento. Faculdade de Ciências da Universidade de Lisboa, 1-363.

Andrade, F.A. L, 1986. O estuário do Mira: Caracterizaçăo geral e análise quantitativa da estrutura dos macropovoamentos bentónicos. Tese de doutoramento, Faculdade de Giências da Universidade de Lisboa, 1-393.

Barr. R. P. G. Watson, C. R Ashcroft. B. E. Bamett and C. Hitton, 1990 Humber estuary - a case study Hydrobiologia 195: 127-143.

Boesch, D. F., M. L. Marvin, LWass and R.W.Virnstein, 1976. The dyramics of estuarine benthic communities, In Estuarine processes, 1, Academic Press: 177-196.

Byliard, G. R. 1987. The value of benthic infauna in manne pollution monitoring studies. Mar. Pollut. Bull, 18 (II): $581-585$.

Daver. D. M. R. M. Ewing and A. J. Rodi, Ir. 1987. Macrobenthic distribution within the sediment along an estuarine salinity gradient. Int. Rev. ges. Hydrobiol. 72 (5): 529-538.

Dexter, D. M., 1979. Cornmunity structure and seasonal variation in intertidal Panamian sandy beaches. Estuar. Coast. Shelf Sci. $9: 543-558$.

Dexter, D. M. 1983. Community structure of intertidal sandy beaches in New South Wales. Australia. In Sandy beaches as ecosystems. Edited by A. McLachlan and T. Erasmus. W. Junk Publishers. The Hague. 461-472

Frontier. S. 1983. Stratégies d'échantillonage en écologie Masson et Les Presses de Luiniversité Laval (ed.). Paris I st ed, 494pp.

Gould, D. J. M. F. Dyer and D. J.Tester, 1987. Environmental quality and ecology of the Great Ouse estuary. Water Pollist Control 1987; 84-103.

Jones, A. R. C.J.Watson-Russel and A. Murray, 1986. Spatial patterns in the macrobenthic communities of the Hawkesbury estuary, New South Wales. Aust. J. Mar. Fresh. Res. 35: 521-543.

Jones.A. R. 1990.Zoobenthic variability associated with a flood and drought in the Hawkesbury estuary. New South Wales: Some consequences for environmental monitoring. Environ. Monit. Assess. 14: 185 - 195.

Lebart, L., A. Morineau and K. M. Warwick, 1984. Multivariate descriptive statistical analysis. Wiley. New York. $231 \mathrm{p}$.

Legendre L and Legendre P, 1984. Ecologie numérique I - Le tratement multiple des données écologiques. II - La structure des données écologiques. Paris, Masson: 1-197 + 1-254.

López-Jamar. E. and J. Mejuto, 1988. Infaunal benthic recolonization after dredging operations in La Coruña bay. NW Spain. Cah. Biol. Mar. 29: 37-49.

196 Marques, J.C. 1989. Importảncia dos Anfípodes nas comunidades bentónicas do estuáno do Mondega in Amphipoda (Crustacea) bentónicos da Costa Portuguesa: Estudo taxonómico, ecológico e biogeografico. Tese Doutoramento em Ecologia Animal, Universidade de Coimbra, 57-187.

Marques. J. C. and A. Nogueira, 1991. Life cycle, population dynamics, and production of Echinogammarus morinus (Leach) (Amphipoda) in the Mondego estuary (Portugal). Oceanol. Acta 11:213-223.

Marques, J. C. L. B. Rodrigues and A. J.A. Nogueira, 1993 a. Intertidal benthic communities structure in the Mondego estuary (westem Portugal): Reference situation. Vie Milieu 43 (2-3): 177-187.

Marques, . C. . P. Maranhäo and M. A. Pardal, 1993 b. Human impact assessment on the subtidal macrobenthic community structure in the Mondego estuary (Western Portugal). Estuar. Coast. Shelf Sci. 37: 403-419.

Mclusky, D. S., 1989. The estuarine ecosystem. Blackje, Glasgow and London, 215 p.

Peet. R. K. 1974. The measurement of species diversity. Annu. Rev. Ecol, Syst. 15: 285-307. 
Rohif. F.J., 1990. NTSYS-pe 1.60. Numencal taxonomy and multivariate analysis system. Exeter Software, New York

Sfriso, A., B. Pavoni and A. Marcomini, 1988. Annual variations of nutrients in the lagoon of Venice Mar. Pollut. Bull. 19 (2): 54-60.

Sfriso, A., A. Marcomini, B. Pavoni and A. Ono, 1990. Eutrofizzazione e macraalgae. La laguna di Venezia come caso exemplare Inquinamento, 4:62-78

Strickland, J. D. and T. R. Parsons, 1968. A practical hand-book of seawater analysis. Bull. Fish. Res. Board Can. 167: $1-311$.

Warwick. R. M. and R. Uncles, 1980. Distribution of benthic macrofauna associations in the Bristol channel in relation to tudal stress. Mar. Ecol. Prog, Ser. 3: 97-103.

Whitfield, A.K. 1989. The benthic invertebrate community of a southern cape estuary. Structure and possible food sources, Trans. Roy. Soc. S.Afr. 47 (2): 159-179.

Zajac, R. N. and R. B. Whitlatch, 1988. Population ecology of the polychaete Nephthys incisa in Long island Sound and the effects of disturbance. Estuaries 11 (2): 117-133. 
Série

Investigação

$\bullet$

Coimbra

Imprensa da Universidade

2002 